\title{
The Semantic Potencial and Functional Characteristics of the Present Tense in Albanian Language
}

\author{
PhD. Alma PINARI (KALLARI) \\ Professor of Russian Language \\ Tirana University \\ Faculty of Foreign Languages \\ Department of Slavic and Balkan Languages \\ Russian language Branch \\ almapinari@gmail.com
}

\begin{abstract}
In the Albanian language grammar as far as synthetic present tense is regarded, the verb (run - vrapoj), has been traditionally called as an undefined tense since it rarely defines a certain moment of the action. On the other hand the analytic form of present continues (po vrapoj - I am running), deals with a certain connection between the action and the moment of speech. The real difference between the undefined action and defined action has always been considered as the main characteristic of the contravention among analytics and synthetics forms of the Albanian language. Actually, the main reason that we use the present tense of the indicative form is to show the way an action is in total accordance with the action of speech. But linguistic facts prove that the action expressed by the present instant transcends the limits of discourse, while fragment of the situation that is in the scope of the speakers at the "moment of speech", as a rule, is part of a whole situation, where the beginning and the end of the action is not affected from it. However, the Albanian language deals with the present tense of verbs just like other forms of the verbs in an attempt to limit the connection between the action and the moment of speech. This happens even in other tenses which may be sort of the same but that stand in different semantic meanings. The scope of this paper is of indicative in Albanian language, the semantic potential and functional features of its synthetic and analytic forms and linguistic interpretation issues of semantic content of this tense. Among other forms of indicative, present tense of Albanian is characterized by large semantics due to the ability of its forms to express not only time relations with the moment of speech (proper temporal semantics), but also how verbal action develops or is distributed in time (aspectual semantics). Idea of time underlies both mentioned semantics, but they stand in different linguistic planes.
\end{abstract}

Keywords: synthetic present, analytic present, concrete/abstract action, potential semantic etc.

\section{Introduction}

In linguistic the semantic aspect of present tense is generally defined as the simultaneity of the action which is expressed at the moment of speech. Kind of the same definition has been introduced even in the Albanian linguistic. The core aim of using the present simple in the Albanian language is to express an action which includes the moment of speech as well. (Grammar of the Albanian Language 1, 2002).

But, as a matter of fact there are some cases in the Albanian language that shows it quiet clearly that the action expressed in the present simple, can overcome the moment of speech, since the fragment of the situation that is taking place is nothing but a slice of all the situations. In other words, the action in the present simple can not express the beginning and the end of the situation. The unfinished situation that takes place in front of the speaker is not only an action that happens at the moment of speech ( for example; look who is coming) but also as an repeated action in the past that has the probability to be repeated even in the present. For example 'Every time he comes to the city he becomes sick.'

The present simple in the Albanian language has been traditionally defined as a synthetic tense which is not defined, because it does not show an action related to a specific moment. While the analytic form of the present tense such as 'I am running' shows a certain connection with the moment of the action since it has the same values for the same moment. The meaning of a certain action/uncertain action has always been seen as a characteristic fact of the contravention between 
the analytic and synthetic forms of the present. The only difference in this contravention is the fact that the action expressed from the verb has a certain relation with past.

\section{The synthetic form (I run)}

The difference between variants of the present tense (run /I'm running) is the semantic counterpoint of current action/noncurrent action (Pinari (Kallari), A., 2013). Such an interpretation justifies the linguists' conclusion that counterpoints in demonstrative manner tense forms serve to indicate not only the timing of an action, but the manner of the operation development and its actualization as well. (Agalliu F., 1968).

The plan to present carries out the categorical meaning of action simultaneity with the reference point (the time of speech). Present tense of demonstrative manner in the Albanian language verbal system consists of synthetic forms such as 'run' (he runs fast) and two types of analytical forms such as 'I'm running' (He is running towards us).

Depending on the different dialects of the Albanian language it can bare different meanings. For instance in the dialect of gegërishte we encounter the version âsht kah ban (A e din qeveria çka asht kah ban Zogu në çerdhe të korbit? (Is the government aware of what happens in the bird's chest?) (S. Drini, Bajram Curri); Jemi kah mundohemi me i ba këto punë si thue ti (We are trying to solve these problems, aren't we?) (S. Drini).

In the grammar of Albanian language the present simple in the sintetic form has always been considered as an undefined form because it has no relation with the period of time. On the other hand the synthetic forms of the present simple such as (I am running) are known as forms that demand the same values and for this reason they are defined as certain actions.

The synthetic present simple has always been described as a typical action or as a typical one. The synthetic form is also used to introduce facts or actions that describe a general truth which is tru in every situation. For example; Every weekend we climb the mountain./ He tends to say the worst things without even thinking about it./etc. however it is worth mentioning that the moment of speech is always part of the synthetic form.

Among different kinds of using the present simple we can also mention those cases when we talk about actions that are regularly repeated or actions that are followed by other actions, during the present. (Demiraj Sh., 1985; (Grammar of the Albanian Language 1, 2002).

For example; Guards are changed every four hours. He enters the tower and lock the door. He kissed her forehead, her eyes and washed her face with his tears. (Gj. Fishta, Lahuta e Malsisë - ritreguar për fëmijë nga O. Grillo).

The semantic potential of the present simple can be described by two major points of view; its paradigm and syntagma. In the first aspect the action tends to give even a specific kind of absurd meaning. So in this case the paradigm of the present simple may express the idea of a concept or of a point of view. For example; 'From the image of the dancer bloomed the melody of death. Which joy of life has not been mixed with the scent of death and sadness? Which glory can stand on the ground without being removed? (Kuteli, E madhe është gjëma e mëkatit).

In another meaning we encounter the meaning of present simple expressing an action that is regularly repeated, that happens frequently or usually, etc. for example; The old dues get to be paid during the next mornings with dark and black spite. (I.Kadare, Mosmarrëveshja);.

On the other hand the synthetic forms of non-current present are used mainly in artistic forms of writing. For example whenever there has to be described a view, a panorama of all that is happening, in scientific literature, journalism, phrases and even lyrics. So, in other hands this form of present simple is used for actions that are always true. (Riza S., 1994).

For example; This place is wonderful because the earth here flourishes during the four seasons, because one can see the snow only once I seven years. And evey time it snows it never really does without vanishing into the air as soon as possible. These green cypresses are the witnesses of many Godness's temples. (M. Kuteli, E madhe është gjëma e mëkatit);

For some countires, mainly those with a big populatin the core of existence is not conditioned by freedom. (I.Kadare, Mosmarrëveshja);

People may die, but their struggles and their faith do not really ever die. (R.Qose);

There where one can notice wealth can notice stingy as well. (Balzak); 
No one ever dies without a reason.

As we can notice from the example that we mentioned above, the present tense in the synthetic form show as certain connection with the speaker at the moment of speech. This happens due to the fact that in this case the idea is to show an action which is always true.

When we talk about present synthetic form there are also other forms of this tense when it works as a past tense or even as a future one. It may be used as a form to express a past action during those times when the action is based on the report among the moment of speech and the chronological order of the events. In this case we can use the synthetic present as a past form. In other words this form is also called a historical present (Praesens historicum). This aims to make the action more vivid and interesting that it might have sound in the past form. (Grammar of the Albanian Language 1, 2002).

For example; After I got out of the office I was walking around thinking about al those officials that sit in their chairs and do nothing but writing. I turn my head I see an old friend of mine...

If we use the present simple in this kind of way what we are doing is the process of making it more actual and bringing it closer to the past. The reason is very simple. Because we want to build a stronger connection between the speaker and the reader/listener. So regarding the grammatical point of view, this kind of usage is in the present simple, while regarding the aspect of meaning this form refers to the past simple tense. The grammatical meaning of this form is highlighted in order to make it more interesting for the listener so that he or she can imagine it as if it is happening now at the moment of speech.

Regarding the future aspect of the present simple we have to understand that it is used only when we want to make a future action a bit more actual. So, the action is clearly going to happen in the future but the verb will be used in the present simple just to make it more interesting and actual for the listener. For example; 'We must be prepared. During these days we expect the Germans to come. (D.Agolli, Njeriu me top).

The action that we are talking about may belong to a near future but it might be used even for a longer period in the future. For example; 'Tomorrow I start the qualification master' or 'Next summer we expect you at our new home'.

In my opinion it is very important to highlight the idea that the figurative meaning of the synthetic present in different contexts does not happen because of its form. No, the grammatical form does not allow it. It is the meaning that gives it the opportunity to be used even for the past or the future. It is because of its synthetic aspect that it has the power to be actualized depending on the situation.

\section{Analytic form of the present simple (I am running)}

In the Albanian language the analitic form of the present simple is achieved by adding the particle 'po', the auxiliary verb 'to be' + the participle of the verb. The semantic feature of this tense is a combination between the period of time where the action takes place and the meaning of the action which is shown by the participle of the verb. Both analytic forms have the same value and be used to replace one and other.

For example: 'What are you doing here? I am rolling in the bedroom with no intention because I do not feel sleepy.'

However, not all the verbs can take the particle ' $p o$ ' in order to create the analytical form of the present. There are some verbs in the Albanian language which lack the ability to be added the particle 'po'. These are mainly the verbs that describe an uncertain period of time suc as; to be, to have, to want, to know, to learn, to be found etc.

In the Albanian language the analytic forms of the present simple are used to express different situations at the moment of speech. For example; Where is Etleva? She is parking the car. (N. Tozaj, Përmbysja). Do you see the other ones? Do you know them? The one who is speaking is Abdyl Frashëri. (Gj. Fishta, vepër e cituar).

The above mentioned verbs are verbs that describe certain actions in a certain moment of the speech. And in this case the particle ' $p o$ ' is used to define the prompt moment of the speech. In the Albanian language the analytic forms of the present simple can also be called as 'actual present'. 
The concrete action happens at the moment of speech even though it might have started before the moment of speech, it still stands out of the concerns of the speaker. The whole attention is on the action that is happening at the moment of speech. For example; Finally it is dawn'. (I.Kadare); He let his pipe down on earth and put his hands on his bladder. - You are hitting me hard" (Sh. Musaraj, Belxhiku që këndon vençe).

Another characteristic of the present simple is the fact that it might be involved into a certain action where we can add existential questions about the action. For example 'What are you doing? - I am having a coffee.; 'What is this silent? They are in a meeting, responded the minors.'. (Dh. Xhuvani, The Tunel).

The existence of the imperative forms in the present tense in the Albanian language has the ability to characterize the present tense with visual and hearing aspects which in the end may also condition or determine the action's period. So, it may contribute in putting the action before or at the moment of speech.

For example; 'The buds are blooming, look, they are flowering.

Thousands of flowers, thousands of love.

\section{(J. Bllaci, Zërat e Natës);}

However in order to express a certain action we do not need to use a lot of specific words. Sometimes it might be enough to just understand the minimal context. For example; 'Suddenly Miti didn't say anything. He got closer to the window and said; They are serving the dinner' (Sh. Musaraj, Belxhiku që këndon vençe).

The actual present that we already mention is also a variant which is widely used even when we write articles or coverages in journalism, when the action is happening at the moment of speech or in front of the speaker. For example; The local residents are being evacuated. The ambulance and the police are approaching scene.

There are also different cases when we can use the actual present for actions that might happen just a few moments after the moment of speech. During these cases the speaker is showing the confidence that the action is going to happen for sure in the near future. For example; "I am going to get some information about the situation - said Skënder and left." ( $N$. Tozaj, Përmbysja);

There was a hunter who has been going out in order to get catch a prey. There he saw a rabbit sleeping in the woods. He smiled happily and started to think; 'I am going to kill this rabbit. I am going to eat its meat and then I am going to sell its fur and get some money. With all the money that I am going to earn I am going to buy a chicken... (Fairytale).

If we would make a short recap to all those things that we mentioned above during this paper, the real situation of the present simple in the Albanian language can be described with the following characteristics:

The imperative forms of present simple carry with it a certain categorical meaning of simultaneity of the moment of speech.

The most important semantic variants of present simple forms are the analytic form or the actual present and the noncurrent form of present or synthetic forms. The meaning of a certain action/uncertain action has always been seen as a characteristic feature of the contravention between the analytic and synthetic forms of the present. The only difference in this contravention is the fact that the action expressed from the verb has a certain relation with past. They are used not only to show the meaning but also to introduce a development and actualization of the action. (Agalliu, F. Studime filologjike 2, 1968; Dhrimo, A. 1996).

The semantic potential of present simple among the feature of analytical forms that expresses the action at the moment of speech, is also characterized by the aspect of actual action. This means that the present simple is a combination between the concrete action, or a located action in the period of time with the feature of expressing the action at the moment of speech. So the action is happening at the moment that we are delivering the speech.

\section{References}

Agalliu F. "About the particle 'po' in the Albanian language" SF.1982, 2,

Agalliu, F. (1968) "Critical observations on the meanings of some tenses". Philological studies 1968/2, P.135. 
Comrie, B. (1976), Aspect An Introduction to the Study of Verbal Aspect and Related Problems, Cambridge: Cambridge univ. Press.

Demiraj, Sh. (1985) "Historical Grammar of the Albanian Language", Tirana, P.713-715, 716, 722, 740. Grammar of the Albanian Language 1 (2002), Academy of Sciences of Albania, Institute of Linguistics and Literature, Tirana, P.30, 274.

Demiraj, Sh. (1971) "The main recent Meanings of the indicative form", Philological studies, 1971/4.

Dodi, A. (1968) "About the use of perfect tenses", Philological studies, 1968/1.

Dhrimo, A. (1996), "Aspect and the verbal modes of tense actions in Albanian language", Publishing House "University Book", Tirana, P. 61, 70, 151-152

Sadiku Z. Transposition of the meanings and aspect of time in the present tense, collection of papers. VII, 1971;

Pinari (Kallari) A. (2014) "Linguistic categorization of temporal tenses in the Albanian language compared to the Russian language". PhD work, Tirana, P. 100-101;

Topalli, K.( 2010), Verbal system of Albanian language, Tirana;

Thelin, Nils B., (1980) "Aspekt und Aktionalität im Russischen", Die Welt der Slawen, Halbjahresschrift für Slawistik, XXV, 2; N. F. IV, 2, P.428-440. Verlag Otto Sagner, München;.

Riza, S. (1994), Verbal system of Albanian contemporary literary language, Academy of Sciences of Albania, Institute of Linguistics and Literature, Tirana, P. 116, 125

Knyazev, J. P. 1977, «Nastoyashee vremya: semantika i pragmatika //Logicheskij analiz yazika, Yazik i vremya», Moskva; Vendler Z. 1967, Verbs and Times //Vendler Z. Linguistics in Philosophy, N.Y.:

Ithaca; 